retailers learned that they had to reduce their margins to persuade money out of people's almost empty pockets. The result, now, is that there is plenty in the shops, but a shortage of customers. The economy seems to be heading for a recession, which will give the country its first taste of unemployment for a long time. Poland has set about learning the law of supply and demand the hard way.

The currency unit, the zloty, has also been devalued to a level at which it is almost feasible to use it as a convertible currency. (US\$1 is now worth about 10,000 zloty.) The results are often bizarre. One laboratory director who had

ordered a sizeable batch of reagents from the West towards the end of last year found himself faced with a bill for nearly 500 million zloty in January. Happenings like that should quickly reduce the demand for imports, but at great cost to those whose work depends on them.

The short-term problem is that of the hardship and dislocation caused by inflation on such a scale. Further ahead lies the question of how Poland will eventually make its way in the world. Most people seem confident that "it'll be all right in ten years". Their problem is that there is no obvious way of getting from here to there.

J.M.

\title{
BIOCHEMISTRY INSTITUTE
}

\section{Short commons for budding researchers}

\section{Warsaw}

THE near-success of the Nazis' ambition to destroy Warsaw means that most buildings have a grey Stalinist stamp, as if the concrete had been mixed with dirty sand or even power-station waste. The Institute of Biochemistry and Biophysics, one of the Polish Academy's best institutes, also has a director's ante-room in the same style, with glass-fronted bookcases and lace curtains on the uncleaned windows.

But the comparison stops at that point. Polish institutes seem to have avoided the endemic gigantism further to the east. The institute has 130 scientists and 75 graduate students, recruited not merely from the University of Warsaw but from all over Poland. Another departure from the usual East European pattern is that the training of specialists for other laboratories and industry is a prime objective.

The research programme covers a general range of topics in molecular biology, from protein folding to the occurrence and function of D-amino acids in organisms (such as D-histidine in Salmonella typhimurum). But director Kazimierz Kleczkowski, himself a plant biochemist who learned much of his trade with James Bonner at the California Institute of Technology, is also proud that his institute has developed a technique based on DNA probes for screening potatoes for infection by RNA viruses.

Poland, he explains, is the "second potato power" in the world, with the result that certificates of freedom from infection are a valuable adjunct of the export trade. Perhaps more important, the laboratory has now also developed a technique for regenerating potato plants from callus tissue, with the result that whole plants can be set growing within 6 weeks. The objective is to breed potatoes resistant to infection by viruses and fungi.

In 1988, institute staff-members published 58 full papers, only 6 of them in Polish. The institute also functions as the coordinator of Poland's national pro-

\section{Eager to grasp autonomy}

\section{Warsaw}

THE Polytechnic University of Warsaw, Poland's MIT, is sited on a city-centre block one must enter as if into an opera house. First, there is an entry-way, with brass-handled swing doors, a cavernous congregation-space with stairways leading off in all directions and then the discovery that all the stairways lead into or alongside a five-storey atrium with the floor-plan of a heptagon with a single axis of symmetry but otherwise unequal sides. There is no proscenium, of course, but instead an almost moorish wedding-cake structure that might have been designed for a performance of Aïda. One day at the end of last month, a beginners' surveying class was hard at work with theodolites on the ground floor, no doubt plotting its shape for the umpteenth time.

What will post-revolutionary freedom, and the new law on higher education in particular, do for the polytechnic university? Rector Marek Roman, while the new law was still before the Sjem, had one ingenious scheme up his sleeve. Polish institutions of higher education provide students with meals and housing at subsidized prices, with funds provided by the state, but are required to recover half the cost from students' pockets, offering grants to those who cannot meet the full costs. The process of assessing students' capacity to pay is always arbitrary and sometimes invidious.

So why not hand over the state subsidy to the students, asking them to administer the communal facilities and to collect partpayment from those they consider can contribute without hardship? The students apparently calculate that they will do the job more efficiently, and fairly, than the university or the state. Rector Roman, taking the new promise of autonomy seriously, is prepared to give the scheme a try.

An even more daring scheme (still only a proposal) is that students failing to meet what is required of them in, say, five years, will be required to pay for the cost of tuition (at present free) in the extra years they spend as students. Considerable proportions at present take six or even seven years to complete their fiveyear course.

Hitherto, Roman says, the system has been too rigid for comfort or the educational interests of the students at the Polytechnic University. Now there will be an opportunity to concentrate on what the university does best. The university also welcomes the promise of greater flexibility in the pattern of the curriculum, previously determined in scrupulous detail by bureaucrats at the education prices to Polish shops. 